\title{
Immunoblot analysis of serological response to Pseudomonas aeruginosa septicaemia in man
}

\author{
RUTH C MATTHEWS, J P BURNIE, S TABAQCHALI \\ Department of Medical Microbiology, St Bartholomew's Hospital, London
}

SUMMARY The occurrence of an outbreak of Pseudomonas aeruginosa septicaemias on an oncology ward permitted an analysis of antibody responses in patients who were all orally exposed to the same source of infection. Seven patients became septicaemic. Serial serum samples were immunoblotted against the homologous strain. Responses were compared with those of 16 other patients with septicaemias caused by other strains and 10 healthy controls. All 18 survivors produced increasing IgG or IgA antibody, or both, against a 35000 dalton band, whereas these antibodies were usually absent or fell in titre in the five fatal cases. These antibodies were also lacking in sera taken just before a patient became septicaemic. This band had the electrophoretic characteristics of the outer membrane porin protein $\mathrm{F}$.

During the past three decades Pseudomonas aeruginosa has emerged from relative obscurity to become a major opportunistic pathogen. ${ }^{1}$ Other Gram negative bacilli have also increased in prevalence, but the number of fatalities due to $P$ aeruginosa is usually the highest. ${ }^{23}$ Some variation in mortality rates probably reflects the geographical distribution of different strains as there is considerable diversity in their degree of virulence. ${ }^{4}$ In some centres mortality is as high as $50 \%$ in leukaemic patients. ${ }^{5}$

Host defence depends on specific antibody and polymorphonuclear phagocytes. ${ }^{6}$ This had led to great interest in the potential of immunotherapy and prophylaxis. ${ }^{458}$ Most vaccine preparations have been based on the lipopolysaccharide (LPS) component of Paeruginosa. Protection is serotype specific. ${ }^{9}$ These have had some success in burns units, ${ }^{1011}$ but clinical trials among patients with cancer $^{512-14}$ and those with cystic fibrosis ${ }^{13}$ gave equivocal results. The high incidence of side effects due to the endotoxic properties of the LPS molecule militates against the use of such vaccines in debilitated patients. ${ }^{512-14}$

Other components of this micro-organism might form safer more effective vaccines in cancer patients. Examination of patients' serological responses to Pseudomonas could help to identify potential vaccine candidates. Many factors, however, determine the outcome of an infection. Apart from host factors, such as the degree of debilitation of the patient, the virulence of Paeruginosa also depends on the strain and the route of challenge. ${ }^{415}$

The occurrence of an outbreak of P aeruginosa septicaemias on a male oncology ward, caused by contaminated thymol mouthwash, ${ }^{1617}$ provided an opportunity to compare serological responses occurring in a population who had all been exposed to the same strain via the same route. The antibody responses to many different components of this micro-organism were examined in a single assay system by combining immunoblotting with reflectance densitometry. Previously it has been shown that immunoblotting can be used as a sensitive quantitative solid phase immunoassay, reflectance densitometry being used to determine the intensity of the stained blots. ${ }^{18}$

Serial sera from other septicaemic patients infected with strains of $P$ aeruginosa not part of the outbreak were also immunoblotted against the outbreak strain to determine whether they produced antibody to the same antigens as patients affected in the outbreak.

\section{Patients and methods}

One hundred serum samples were examined from 23 patients with Paeruginosa septicaemia, multiple serum samples (two to seven) being collected from each patient. All patients had clinical features of septicaemia corresponding to positive blood cultures. 
Table 1 Details of patients affected by outbreak of Pseudomonas aeruginosa septicaemias in male oncology ward

\begin{tabular}{|c|c|c|c|c|c|}
\hline \multirow[b]{2}{*}{$\begin{array}{l}\text { Case } \\
\text { number }\end{array}$} & \multirow[b]{2}{*}{$\begin{array}{l}\text { Age } \\
\text { (years) }\end{array}$} & \multirow[b]{2}{*}{$\begin{array}{l}\text { Underlying } \\
\text { disorders }\end{array}$} & \multicolumn{2}{|c|}{ Duration of neutropenia (days) } & \multirow[b]{2}{*}{$\begin{array}{l}\text { Pseudomonas } \\
\text { infection }\end{array}$} \\
\hline & & & $<0.5$ & $0.6-2.0 \times 10^{9} / 1$ & \\
\hline $\begin{array}{l}1 \\
2 \\
3 \\
4 \\
5^{*} \\
6 \\
7\end{array}$ & $\begin{array}{l}17 \\
49 \\
47 \\
21 \\
37 \\
48 \\
44\end{array}$ & $\begin{array}{l}\text { Non-Hodgkin's lymphoma } \\
\text { Non-Hodgkin's lymphoma } \\
\text { Acute myeloblastic leukaemia } \\
\text { Acute myeloblastic leukaemia } \\
\text { Non-Hodgkin's lymphoma } \\
\text { Refractory anaemia with excess blasts } \\
\text { Acute myeloblastic leukaemia }\end{array}$ & $\begin{array}{r}12 \\
11 \\
10 \\
10 \\
10 \\
5 \\
2\end{array}$ & $\left.\begin{array}{r}3 \\
6 \\
10 \\
3 \\
2 \\
1 \\
9\end{array}\right\}$ & Septicaemic \\
\hline $\begin{array}{r}8 \\
9 \\
10\end{array}$ & $\begin{array}{l}37 \\
53 \\
43\end{array}$ & $\begin{array}{l}\text { Acute myeloblastic leukaemia } \\
\text { Non-Hodgkin's lymphoma } \\
\text { Hodgkin's disease }\end{array}$ & $\begin{array}{l}8 \\
0 \\
0\end{array}$ & $\left.\begin{array}{l}0 \\
0 \\
0\end{array}\right\}$ & Infected \\
\hline $\begin{array}{l}11 \\
12 \\
13\end{array}$ & $\begin{array}{l}67 \\
48 \\
54\end{array}$ & $\begin{array}{l}\text { Acute myeloblastic leukaemia } \\
\text { Acute myeloblastic leukaemia } \\
\text { Chronic lymphocytic leukaemia }\end{array}$ & $\begin{array}{l}2 \\
0 \\
0\end{array}$ & $\left.\begin{array}{r}6 \\
10 \\
0\end{array}\right\}$ & Uninfected \\
\hline
\end{tabular}

*Patient died.

Seven of the patients were part of an outbreak on an oncology ward at St Bartholomew's Hospital due to a strain of serotype 01 and phage type 7, 21, 44, 68, F8, 109 119X, 352, 1214, M4. ${ }^{16}{ }^{17}$ Thymol mouthwash, which had been made up and distributed in communal jugs, was the likely source of this outbreak. Of the 13 patients on the ward, seven developed septicaemia (table 1). Their blood culture isolates were indistinguishable by conventional typing methods from the strain isolated from the thymol mouthwash. The same strain was cultured from the mouth or rectum, or both, of the septicaemic patients and also three patients on the ward who were colonised but not septicaemic. Sera from the infected patients and also from the three uninfected patients on the ward were examined. All the patients were adult males (average age 38 years, range 17 to 49 years) receiving cytotoxic chemotherapy for haematological malignancies. All were exposed to the same strain of $P$ aeruginosa by the same route (oral). Septicaemic patients were treated with tobramycin and ticarcillin and clavulanate (timentin). One of them died from the infection.

The results from these patients were compared with those of the other 16 septicaemic adults with positive blood cultures who were not part of the outbreak and who were infected with different strains of Paeruginosa. Four of these patients died. Eight had haematological malignancies. Sera from 10 healthy blood donors were also examined.

\section{PREPARATION OF IMMUNOBLOTS}

The outbreak strain of $P$ aeruginosa was grown aerobically at $37^{\circ} \mathrm{C}$ overnight on blood agar plates (Oxoid). It was harvested, washed in sterile distilled water, and ruptured in a Mickle cell disintegrator using glass balls for 10 minutes. The extract was spun at $12000 \mathrm{~g}$ for 10 minutes and the supernatant then used, applying $50 \mu \mathrm{g}$ to each well of a $10 \%$ acrylamide gel. A single batch of this preparation was used throughout these experiments. It was separated by sodium dodecyl sulphate polyacrylamide gel electrophoresis (SDS-PAGE), and immunoblotting was performed as previously described. ${ }^{19}$ Briefly, transfer to nitrocellulose membranes was achieved in a transblotting chamber (BioRad Laboratories, Richmond, California), at $90 \mathrm{~V}$ and $350 \mathrm{~mA}$ for one and a half hours, using $25 \mathrm{mM}$ Tris, $192 \mathrm{mM}$ glycine in $20 \%$ methanol (pH 8.3). Nitrocellulose strips were then incubated overnight at $4^{\circ} \mathrm{C}$ in $3 \%$ bovine serum albumin (BSA) in buffered saline.

Each strip was then incubated for two hours at room temperature with the patient's serum, diluted $1 / 6$ with $3 \%$ BSA, $0.05 \%$ Tween 20 (BioRad), in buffered saline. After washing in $0.9 \%$ saline and $0.05 \%$ Tween 20 strips were incubated for one hour at room temperature with alkaline-phosphatase conjugated goat antihuman IgM, IgG, or IgA (Sigma Chemical, St Louis, Missouri). The conjugate was diluted $1 / 1000$ immediately before use in 3\% BSA in buffered saline. After washing strips were incubated in a freshly prepared and filtered mixture of equal volumes of naphthol AS-MX phosphate (Sigma; $0.4 \mathrm{mg} / \mathrm{ml}$ in distilled water) and fast red TR salt (Sigma; $6 \mathrm{mg} / \mathrm{ml}$ in $0.2 \mathrm{M}$ Tris, $\mathrm{pH} 8.2$ ). Antigenantibody binding was identified by deposition of red stain. The intensity of each band, measured by reflectance densitometry (Chromoscan 3; Joyce Loebl), was proportional to the amount of antibody present in the serum, as discussed by Towbin and Gordon. ${ }^{18}$

Sera from six patients with high titres of antibody to a $35 \mathrm{k}$ band were also immunoblotted using the conditions recommended for protein $F,{ }^{2021}$ in the SDS-PAGE system described by Lugtenberg et al. ${ }^{22}$ 
Table 2 Antibody responses of septicaemic patients against seven pseudomonal antigens

\begin{tabular}{|c|c|c|c|c|c|c|c|}
\hline \multirow{3}{*}{$\begin{array}{l}\text { Molecular } \\
\text { weight } \\
(k)\end{array}$} & \multirow{3}{*}{$\begin{array}{l}\text { Antibody } \\
\text { titres }\end{array}$} & \multicolumn{6}{|l|}{ Immunoglobulin } \\
\hline & & \multicolumn{2}{|l|}{$\operatorname{Ig} M$} & \multicolumn{2}{|l|}{$\operatorname{Ig} G$} & \multicolumn{2}{|l|}{$\operatorname{Ig} A$} \\
\hline & & Survived & Died & Survived & Died & Survived & Died \\
\hline \multirow[t]{2}{*}{89} & \multirow{2}{*}{$\begin{array}{l}\text { Increase } \\
\text { Constant } \\
\text { Decrease } \\
\text { Undetectable }\end{array}$} & $\begin{array}{l}2 \\
1\end{array}$ & & $\begin{array}{l}3 \\
3\end{array}$ & 1 & $\begin{array}{l}1 \\
2\end{array}$ & \\
\hline & & 15 & 5 & 12 & 3 & 15 & $\begin{array}{l}1 \\
4\end{array}$ \\
\hline \multirow[t]{2}{*}{42} & \multirow{2}{*}{$\begin{array}{l}\text { Increase } \\
\text { Constant } \\
\text { Decrease } \\
\text { Undetectable }\end{array}$} & 3 & 2 & $\begin{array}{l}4 \\
3\end{array}$ & $\begin{array}{l}1 \\
2\end{array}$ & $\begin{array}{l}5 \\
2\end{array}$ & \multirow{2}{*}{$\begin{array}{l}1 \\
1 \\
3\end{array}$} \\
\hline & & 15 & 3 & 11 & 2 & 11 & \\
\hline \multirow[t]{2}{*}{35} & Increase & $\begin{array}{l}7 \\
3\end{array}$ & & $\begin{array}{r}13 \\
5\end{array}$ & 1 & $\begin{array}{r}14 \\
2\end{array}$ & \multirow[b]{2}{*}{$\begin{array}{l}4 \\
1\end{array}$} \\
\hline & $\begin{array}{l}\text { Decrease } \\
\text { Undetectable }\end{array}$ & 8 & $\begin{array}{l}1 \\
4\end{array}$ & & $\begin{array}{l}2 \\
2\end{array}$ & 2 & \\
\hline \multirow[t]{2}{*}{34} & \multirow{2}{*}{$\begin{array}{l}\text { Increase } \\
\text { Constant } \\
\text { Decrease } \\
\text { Undetectable }\end{array}$} & $\begin{array}{l}4 \\
2\end{array}$ & 1 & $\begin{array}{l}4 \\
4\end{array}$ & & $\begin{array}{l}7 \\
2\end{array}$ & \multirow[b]{2}{*}{$\begin{array}{l}1 \\
4\end{array}$} \\
\hline & & 12 & 4 & 10 & $\begin{array}{l}2 \\
3\end{array}$ & 9 & \\
\hline \multirow[t]{2}{*}{32} & \multirow{2}{*}{$\begin{array}{l}\text { Increase } \\
\text { Constant } \\
\text { Decrease } \\
\text { Undetectable }\end{array}$} & $\begin{array}{l}3 \\
2\end{array}$ & 1 & $\begin{array}{l}4 \\
4\end{array}$ & 1 & $\begin{array}{l}8 \\
1\end{array}$ & \multirow[b]{2}{*}{$\begin{array}{l}1 \\
4\end{array}$} \\
\hline & & 13 & 4 & 10 & $\begin{array}{l}1 \\
3\end{array}$ & 9 & \\
\hline \multirow[t]{2}{*}{31} & \multirow{2}{*}{$\begin{array}{l}\text { Increase } \\
\text { Constant } \\
\text { Decrease } \\
\text { Undetectable }\end{array}$} & $\begin{array}{l}2 \\
2\end{array}$ & 1 & $\begin{array}{l}5 \\
2\end{array}$ & & $\begin{array}{l}8 \\
1\end{array}$ & \multirow[b]{2}{*}{$\begin{array}{l}1 \\
4\end{array}$} \\
\hline & & 14 & 4 & 11 & $\begin{array}{l}1 \\
4\end{array}$ & 9 & \\
\hline \multirow[t]{2}{*}{28} & \multirow{2}{*}{$\begin{array}{l}\text { Increase } \\
\text { Constant } \\
\text { Decrease } \\
\text { Undetectable }\end{array}$} & $\begin{array}{l}2 \\
1\end{array}$ & & $\begin{array}{l}5 \\
2\end{array}$ & & 8 & \multirow[b]{2}{*}{$\begin{array}{l}1 \\
4\end{array}$} \\
\hline & & 15 & 5 & 11 & 5 & 10 & \\
\hline
\end{tabular}

Increase and decrease refer to a change in densitometry of $>30 \%$ and constant to changes of $<20 \%$.

Using this system the extract was solubilised in $2 \%$ SDS-5\% 2-mercaptoethanol at $100^{\circ} \mathrm{C}$ for five minutes and run on a $14 \%$ acrylamide gel.

\section{Results}

Twenty six antigenic bands (23 to 141 kilodaltons) were distinguishable in this preparation of $P$ aeruginosa using the immunoblot technique. The antibody responses to 19 bands remained constant in at least 22 of the 23 patients during the course of the septicaemias. Only three of these bands $(45,40$, and $37 k)$ were recognised by more than five patients. The densitometry of antibodies binding to the remaining seven bands $(89,42,35,34,32,31$ and $28 \mathrm{k})$ changed by $>30 \%$ during the course of the septicaemias (table 2). All 18 surviving patients produced increasing IgG or IgA antibodies, or both against the $35 \mathrm{k}$ band, and at

Table 3 Densitometry of the antibody response in septicaemic patient in outbreak who survived

\begin{tabular}{|c|c|c|c|c|c|c|c|c|c|}
\hline \multirow{2}{*}{$\begin{array}{l}\text { Molecular } \\
\text { weight } \\
(k)\end{array}$} & \multicolumn{3}{|c|}{ Serum (i) } & \multicolumn{3}{|c|}{ Serum (ii) } & \multicolumn{3}{|c|}{ Serum (iii) } \\
\hline & $\overline{\operatorname{Ig} M}$ & $\operatorname{Ig} G$ & $\operatorname{Ig} A$ & $\overline{I g M}$ & $\operatorname{Ig} G$ & $\operatorname{Ig} A$ & $\overline{\operatorname{Ig} M}$ & $\operatorname{Ig} G$ & $\operatorname{Ig} A$ \\
\hline $\begin{array}{l}42 \\
35 \\
34 \\
32 \\
31 \\
28\end{array}$ & 96 & $\begin{array}{r}78 \\
41 \\
20 \\
10 \\
17 \\
2\end{array}$ & $\begin{array}{l}27 \\
12\end{array}$ & $\begin{array}{r}95 \\
32 \\
19 \\
10 \\
2\end{array}$ & $\begin{array}{r}86 \\
51 \\
29 \\
12 \\
19 \\
2\end{array}$ & $\begin{array}{l}99 \\
76 \\
35 \\
26 \\
15\end{array}$ & $\begin{array}{r}93 \\
50 \\
25 \\
12 \\
17 \\
6\end{array}$ & $\begin{array}{r}166 \\
126 \\
96 \\
55 \\
51 \\
25\end{array}$ & $\begin{array}{r}157 \\
108 \\
71 \\
39 \\
28 \\
12\end{array}$ \\
\hline
\end{tabular}

Height of densitometry traces in mm for IgM, IgG, and IgA. Sera collected (i) one week before hospital admission; (ii) when the patient became clinically septicaemic; and (iii) during the recovery phase. 


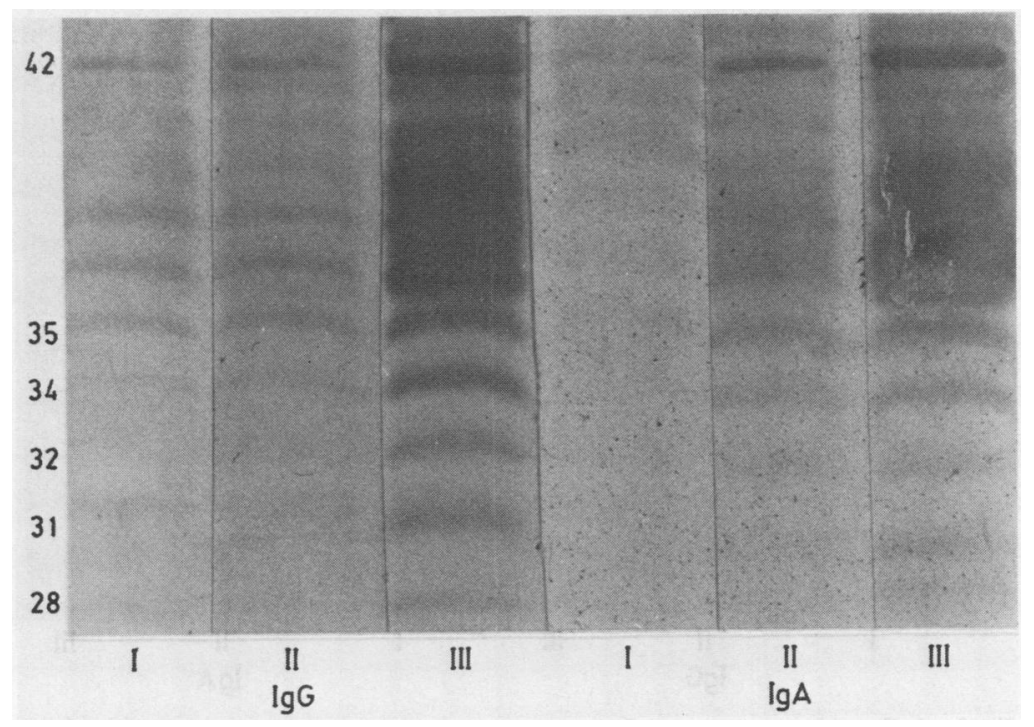

Fig $1 \operatorname{IgG}$ and $\operatorname{Ig} A$ response to $P$ aeruginosa in septicaemic patient in outbreak who survived. Sera shown were taken (i) one week before hospital admission, (ii) when the patient became clinically septicaemic, and (iii) during recovery phase.

least eight of the surviving patients produced rising titres to bands of $34,32,31$ and $28 \mathrm{k}$. Falling titres to these five bands were not observed during the septicaemic phase of any of the patients who recovered. Rising antibody titres to the 89 and $42 \mathrm{k}$ bands were relatively uncommon (less than five patients).

Table 3 and fig 1 show a representative example of the serological response to the homologous strain. This was a septicaemic patient from the outbreak who recovered. Initially there was relatively little $(<50 \mathrm{~mm}$ ) IgM, IgG, and IgA to the $35,34,32,31$ and $28 \mathrm{k}$ bands, but titres rose over three-fold after the patient became septicaemic and during recovery. Similar serological responses to these bands occurred in surviving patients who were not part of the outbreak, whose sera were immunoblotted against the outbreak strain of $P$ aeruginosa. The patient shown in fig 1 also had increases in the antibodies to antigens of $36-42 \mathrm{k}$, but the rise in IgM to these bands was much less pronounced (table 3 ).

In four of the five fatal cases $\operatorname{IgG}$ and $\operatorname{IgA}$ to bands $35,34,32,31$ and $28 \mathrm{k}$ were either undetectable or faded terminally (table 2 ). The fifth fatal case showed a small rise in IgG to the 35 and $32 \mathrm{k}$ bands with a concomitant disappearance of $\operatorname{IgA}$ to these antigens.

Fig 2 shows representative immunoblots from the one patient in the outbreak who died. The IgG and IgA titres to bands $35,34,32$ and $31 \mathrm{k}$ rose little, if at all, when the patient became clinically septicaemic, and these fell over the next four days so that IgG and IgA were greatly reduced $(<20 \mathrm{~mm})$ in terminal sera (table 4). In contrast, the IgM titres to the 35, 34, 32 and $31 \mathrm{k}$ bands remained high $(>100 \mathrm{~mm})$. This patient also had a high titre of pre-existing IgG

Table 4 Densitometry of antibody response in septicaemic patient in outbreak who died

\begin{tabular}{|c|c|c|c|c|c|c|c|c|c|}
\hline \multirow{2}{*}{$\begin{array}{l}\text { Molecular } \\
\text { weight } \\
(k)\end{array}$} & \multicolumn{3}{|c|}{ Serum (i) } & \multicolumn{3}{|c|}{ Serum (ii) } & \multicolumn{3}{|c|}{ Serum (iii) } \\
\hline & $\overline{I g} M$ & $\operatorname{Ig} \bar{G}$ & $\operatorname{Ig} A$ & $\operatorname{IgM}$ & $\operatorname{Ig} G$ & $\operatorname{Ig} A$ & $I g M$ & $\operatorname{Ig} G$ & $\operatorname{Ig} A$ \\
\hline $\begin{array}{l}42 \\
35 \\
34 \\
32 \\
31 \\
28\end{array}$ & $\begin{array}{r}62 \\
137 \\
149 \\
144 \\
102 \\
34\end{array}$ & $\begin{array}{l}52 \\
18 \\
24 \\
30 \\
23\end{array}$ & $\begin{array}{l}15 \\
50 \\
62 \\
53 \\
26\end{array}$ & $\begin{array}{r}64 \\
141 \\
152 \\
148 \\
105 \\
42\end{array}$ & $\begin{array}{l}55 \\
24 \\
32 \\
38 \\
28\end{array}$ & $\begin{array}{r}2 \\
26 \\
28 \\
31 \\
21\end{array}$ & $\begin{array}{r}43 \\
119 \\
131 \\
128 \\
103 \\
58\end{array}$ & $\begin{array}{r}49 \\
17 \\
12 \\
9 \\
14\end{array}$ & $\begin{array}{r}1 \\
18 \\
18 \\
17 \\
16\end{array}$ \\
\hline
\end{tabular}

Height of densitometry traces in mm for IgM, IgG, and IgA. Sera collected (i) six months before hospital admission; (ii) when the patient became clinically septicaemic; and (iii) four days later, a day before he died. 


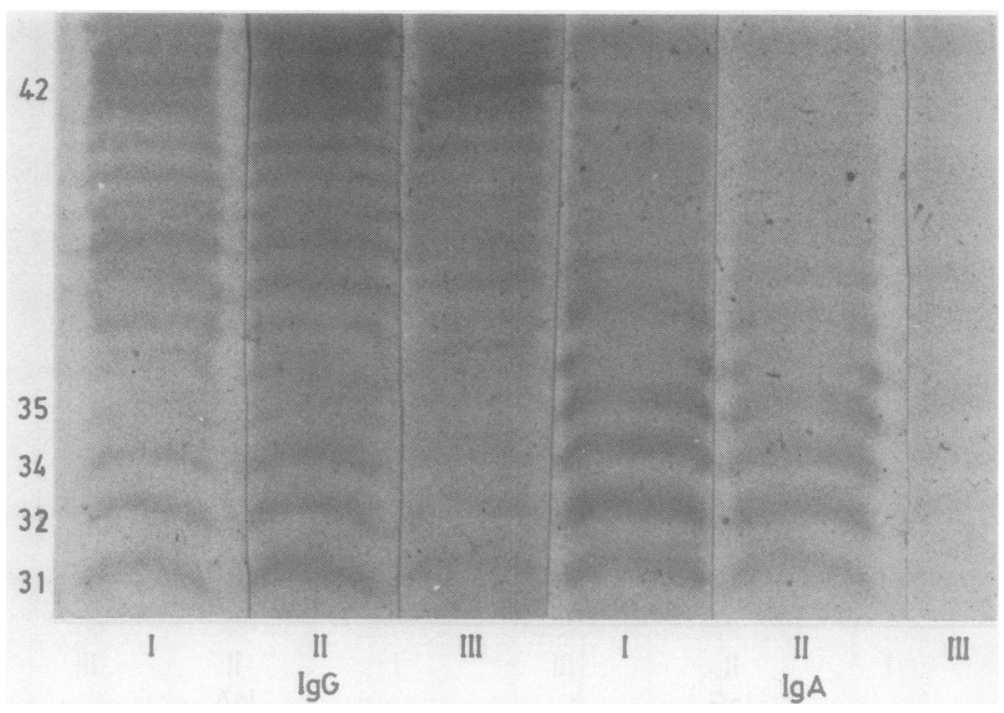

Fig $2 \operatorname{Ig} G$ and $\operatorname{Ig} A$ response to $P$ aeruginosa in septicaemic patient in outbreak who died. Sera shown were taken (i) six months before hospital admission, (ii) when patient became clinically septicaemic, and (iii) four days later, one day before he died.

Molecular weights $(k)$ are given beside figs 1 and 2 .

$(148 \mathrm{~mm})$ to the $71 \mathrm{k}$ band but this remained constant at 150 (SD 15) $\mathrm{mm}$

Early sera, taken when positive blood cultures were collected, were available from 14 of the septicaemic patients and provided information on the titres of antibodies at the onset of septicaemia. $\operatorname{IgA}$ to the $35 \mathrm{k}$ band was invariably undetectable at this stage and also usually lacking to bands $34,32,31$ and $28 \mathrm{k}$ (table 5 ). IgG to the $35 \mathrm{k}$ antigen was detectable in only two patients at this time and in each case was $<50 \mathrm{~mm}$. In contrast, $\operatorname{IgG}$ and $\operatorname{IgA}$ to the 89 and $42 \mathrm{k}$ bands were often present in these early sera.

Sera were collected from six patients in the outbreak who did not become septicaemic, despite being exposed to the infected thymol mouthwash. The out break strain of Paeruginosa was found in the gastro intestinal tracts of three patients, and all three had a notable lack of IgA to bands $35,34,32,31$ and $28 \mathrm{k}$ (table 5). Two of the infected patients had IgG to all five of these bands. The three other patients resisted gastrointestinal colonisation and they had $\operatorname{IgA}$, as well as IgG, to the $35 \mathrm{k}$ band and some of the 34,32 , 31 and $28 \mathrm{k}$ bands.

Examination of sera from 10 healthy blood donors showed that IgM to pseudomonal antigens is not uncommon. Four of 10 subjects had IgM to the $35 \mathrm{k}$ band but only one had either IgG $(21 \mathrm{~mm})$ or $\operatorname{IgA}$ $(33 \mathrm{~mm})$ to this band (table 5).

Table 5 Antibody present in early sera from 14 septicaemic patients, non-septicaemic patients in the outbreak and healthy controls

\begin{tabular}{|c|c|c|c|c|c|c|c|c|c|c|c|c|}
\hline \multirow{3}{*}{$\begin{array}{l}\text { Molecular } \\
\text { weight } \\
(k)\end{array}$} & \multirow{2}{*}{\multicolumn{3}{|c|}{ Septicaemic (early sera) }} & \multicolumn{9}{|c|}{ Non-septicaemic } \\
\hline & & & & \multicolumn{3}{|c|}{$\begin{array}{l}\text { Infected with } \\
\text { outbreak strain } 3\end{array}$} & \multicolumn{3}{|c|}{$\begin{array}{l}\text { Not infected with } \\
\text { outbreak strain } 3\end{array}$} & \multicolumn{3}{|c|}{$\begin{array}{l}\text { Healthy controls } \\
10\end{array}$} \\
\hline & $I g M$ & $\operatorname{Ig} G$ & $\operatorname{Ig} A$ & $\overline{\operatorname{Ig} M}$ & $\operatorname{Ig} G$ & $\operatorname{Ig} A$ & $I g M$ & $I g G$ & $\operatorname{Ig} A$ & $\operatorname{IgM}$ & $I g G$ & $\operatorname{Ig} A$ \\
\hline $\begin{array}{l}89 \\
42 \\
35 \\
34 \\
32 \\
31 \\
28\end{array}$ & $\begin{array}{l}2 \\
6 \\
1 \\
1 \\
2 \\
1\end{array}$ & $\begin{array}{l}8 \\
9 \\
2 \\
2 \\
3 \\
1\end{array}$ & $\begin{array}{l}3 \\
9 \\
2\end{array}$ & 3 & $\begin{array}{l}1 \\
1 \\
2 \\
2 \\
2 \\
2 \\
2\end{array}$ & 2 & $\begin{array}{l}2 \\
1\end{array}$ & $\begin{array}{l}3 \\
3 \\
3 \\
2 \\
3\end{array}$ & $\begin{array}{l}3 \\
3 \\
2 \\
2 \\
1\end{array}$ & $\begin{array}{l}4 \\
4 \\
3 \\
\end{array}$ & $\begin{array}{l}5 \\
1 \\
2\end{array}$ & $\begin{array}{l}5 \\
1\end{array}$ \\
\hline
\end{tabular}


When SDS-PAGE conditions were adjusted to those recommended for outer membrane proteins, the $35 \mathrm{k}$ band migrated to the $39 \mathrm{k}$ position, characteristic of protein $\mathrm{F}^{2021}$ The bands of molecular weights 34, 32,31 and $28 \mathrm{k}$ also changed their relative mobilities when the conditions of electrophoresis and solubilisation changed. Their apparent molecular weights were comparable with those of the minor outer membrane proteins described by Hancock et al. ${ }^{20} 21$

\section{Discussion}

The occurrence of an outbreak of Paeruginosa septicaemias on an oncology ward provided the opportunity to compare antibody responses in seven septicaemic patients, three asymptomatically infected patients, and three uninfected patients, all of whom were exposed to a common oral source. Hancock et al used the immunoblotting technique qualitatively to assess the serological response of patients with cystic fibrosis to Paeruginosa. ${ }^{21}$ It could not be used to compare patients' responses quantitatively because of variations in the amount of some proteins present in different strains. ${ }^{23}$ Because of the outbreak, it was possible to compare the responses to the homologous strain of 13 patients, multiple sera being assayed in parallel on a single gel. Sera from septicaemic patients infected with strains not associated with the outbreak were also assayed against the outbreak strain to determine whether antibody responses were type specific.

A relatively small number of bands were consistently associated with pronounced changes in antibody titres during the course of the septicaemias. These bands, of $35,34,32,31$ and $28 \mathrm{k}$, had the unusual electrophoretic characteristics of outer membrane proteins. ${ }^{2021}$ There was surprisingly little evidence of a strong type specific response to LPS, although this could have been partly masked by the fact that after electrophoresis LPS appears as multiple bands over a wide range of molecular weights and not as a discrete component. ${ }^{24}$ Antibodies to LPS seem to be protective in infections in experimental animals ${ }^{25-27}$; Pollack and Young correlated the development of these antibodies with survival in man. ${ }^{28}$ In a later paper, however, Pollack et al found a significant increase in haemagglutinating titres to type specific LPS in only three of 17 infected patients. ${ }^{29}$

The $35 \mathrm{k}$ antigen seemed to be the major outer membrane protein, protein $\mathrm{F}$, as its apparent molecular weight changed from $35 \mathrm{k}$ on a $10 \%$ acrylamide gel to $39 \mathrm{k}$ on a $14 \%$ gel using the conditions recommended for the characterisation of this protein. ${ }^{2021}$ The $28-34 \mathrm{k}$ bands were probably minor outer membrane proteins. The immunogenicity of outer membrane proteins from $P$ aeruginosa has been shown in mice $^{30}$ and $\operatorname{man}^{2131}$ : they have the advantage over LPS of being highly conserved between different serotypes. ${ }^{23} \mathrm{~A}$ preparation of protein $\mathrm{F}$ has been used as a protective vaccine in mice, ${ }^{32}$ and monoclonal antibodies to protein $\mathrm{F}$ passively immunised mice against Paeruginosa. ${ }^{33}$

In this analysis all patients surviving the septicaemia produced IgG or IgA responses, or both, to protein $\mathrm{F}$, and in four of the five fatal cases IgG and IgA were undetectable or faded terminally. This was not merely a reflection of the general state of the immune system as the antibody titres to many of the other bands remained constant during the course of the septicaemias. Moreover, in some fatal cases IgG and IgA to protein $\mathrm{F}$ fell, whereas IgM remained high and constant (table 4).

Antibodies developing during septicaemia may be a passive or correlative marker of survival rather than a prime determinant of ability to contain spread of infection. Some evidence to suggest that the antibody to protein $F$ is protective is given by the analysis of antibodies present in patients who did not become septicaemic. Patients who became neither infected nor septicaemic had both IgA and IgG to the $35 \mathrm{k}$ band. The three asymptomatically infected patients invariably lacked IgA to this band; one of these patients was severely neutropenic (white cell count $<0.5 \times$ $10^{9} / 1$ ) but had $\operatorname{IgG}$ to protein $\mathrm{F}$, which may have inhibited systemic spread. Early sera from septicaemic patients in the outbreak invariably lacked IgA and usually IgG to protein F. Gastrointestinal infection is an important preliminary step to septicaemia in patients with cancer, ${ }^{34}$ and it would be valuable to establish whether IgA to protein $\mathrm{F}$ can help prevent this.

Only some of the healthy controls had antibodies to the $35 \mathrm{k}$ band, and usually this was of the IgM class, the presence of which was not associated with survival in septicaemic patients. This shows the contribution of other factors in preventing pseudomonas septicaemia, in particular an intact gastrointestinal mucosa and neutrophils. ${ }^{6}$ Table 1 illustrates that survival did not solely depend on the rate of recovery from neutropenia, four of the survivors being no less neutropenic than the patient who died in the outbreak. One of the infected patients who remained aseptic was also severely neutropenic for eight days.

Previously protein $\mathrm{F}$ antibodies have been shown by immunoblotting techniques in the serum of patients with cystic fibrosis and chronic pulmonary infection with Paeruginosa, ${ }^{21}$ and, using crossimmunoelectrophoresis, in one of four septicaemic patients with acute leukaemia. ${ }^{31}$ It has been postulated that the presence of these antibodies contributes to the rarity of bacteraemia in cystic fibrosis. ${ }^{21}$ This paper reports for the first time an association between 
the production of antibody to protein $\mathrm{F}$ and survival from $P$ aeruginosa septicaemia in patients on an oncology ward. Pre-existing IgA and IgG to protein F was associated with absence of infection and septicaemia, respectively, in similar neutropenic patients exposed to the same source of infection. This suggests that an alternative to LPS vaccines in such patients might be the outer membrane proteins of $P$ aeruginosa, an approach which is already being pursued for Haemophilus influenzae $e^{35}$ and Neisseria gonorrhoeae. ${ }^{36}$

\section{References}

1 Cross AS. Evolving epidemiology of Pseudomonas aeruginosa infections. Eur J Clin Microbiol 1985;4:156-9.

2 Bryan CS, Reynolds KL, Brenner ER. Analysis of 1,186 episodes of Gram negative bacteremia in non-university hospitals: the effect of antimicrobial therapy. Rev Infect Dis 1983;5:629-38.

3 Cryz SJ. New insights into the epidemiology, pathogenesis and therapy of Pseudomonas aeruginosa infections. Eur J Clin Microbiol 1985;4:153-5.

4 Zellner PR, Metzger E, Zwisler O. Active immunisation against Pseudomonas aeruginosa in burns. In: Urbaschek B, Urbaschek R, Neter E, eds. Gram negative bacterial infections. New York: Springer-Verlag, 1973:499-500.

5 Young LS, Pollack MS. Immunologic approaches to the prophylaxis and treatment of Pseudomonas aeruginosa infections. In: Sabath LD, ed. Pseudomonas aeruginosa: the organism, diseases it causes, and their treatment. Vienna: Hans Huber, 1980:119-32.

6 Young LS, Armstrong D. Human immunity to Pseudomonas aeruginosa. I. In vitro interactions of bacteria, polymorphonuclear leukocytes and serum factors. $J$ Infect Dis 1972;126: 257-76.

7 Jones RJ. Immunisation against pseudomonas infection. In: Easmon CSF, Jeljaszewitz J, eds. Medical microbiology II. Immunisation against bacterial disease. New York: Academic Press, 1982:177-205.

8 Homma JY. Perspectives on the development of a new vaccine against Pseudomonas aeruginosa infection. In: Easmon CSF, Jeljaszewitz J, eds. Medical Microbiology II. Immunisation against bacterial disease. New York: Academic Press, 1982:389-431

9 Miler JM, Spilsbury JF, Jones RJ, Roe EA, Lowbury EJL. A new polyvalent pseudomonas vaccine. J Med Microbiol 1977;10: 19-27.

10 Alexander JW, Fisher MW. Immunization against Pseudomonas infection after thermal injury. J Infect Dis 1974;130(S):152-65.

11 Jones RJ, Roe EA, Gupta JL. Controlled trial of Pseudomonas immunoglobulin and vaccine in burn patients. Lancet 1980;ii:1263-5.

12 Young LS, Meyer RD, Armstrong D. Pseudomonas aeruginosa vaccine in cancer patients. Ann Intern Med 1973;79:518-27.

13 Pennington JE. Preliminary investigation of Pseudomonas aeruginosa vaccine in patients with leukemia and cystic fibrosis. $J$ Infect Dis 1974;130(S):159-62.

14 Haghbin M, Armstrong D, Murphy ML. Controlled prospective trial of Pseudomonas aeruginosa vaccine in children with acute leukemia. Cancer 1973;32:761-66.

15 Homma JY. Roles of exoenzymes and exotoxin in the pathogenicity of Pseudomonas aeruginosa and the development of a new vaccine. Japanese Journal of Experimental Medicine 1980;50:149-65.

16 Stephenson JR, Heard SR, Richards MA, Tabaqchali S. Outbreak of septicemia due to a contaminated mouthwash. Br Med $J$ 1984;289:1584.

17 Stephenson JR, Heard SR, Richards MA, Tabaqchali S. Gastrointestinal colonisation and septicemia with Pseudomonas aeruginosa due to contaminated thymol mouthwash in immu- nocompromised patients. J Hosp Infect 1985;6:369-78.

18 Towbin $\mathrm{H}$, Gordon J. Immunoblotting and dot immunobinding - current status and outlook. J Immunol Methods 1984;72:313-40.

19 Matthews RC, Burnie JP, Tabaqchali S. Immunoblot analysis of the serological response in systemic candidosis. Lancet 1984;ii:1415-8.

20 Hancock REW, Carey AM. Outer membrane of Pseudomonas aeruginosa: heat and 2-mercaptoethanol-modifiable proteins. J Bacteriol 1979;140:902-10.

21 Hancock REW, Mouat ECA, Speert DP. Quantitation and identification of antibodies to outer membrane proteins of Pseudomonas aeruginosa in sera of patients with cystic fibrosis. $J$ Infect Dis 1984;149:220-6.

22 Lugtenberg B, Meijers J, Peters R, van der Hoek P, van Alphen L. Electrophoretic resolution of the "major outer membrane protein" of Escherichia coli K12 into four bands. FEBS Let 1975;58:254-8.

23 Mutharia LM, Nicas TI, Hancock REW. Outer membrane proteins of Pseudomonas aeruginosa serotype strains. J Infect Dis 1982;146:770-9.

24 Cryz SJ, Pitt TL, Furer E, Germanier R. Role of lipopolysaccharide in virulence of Pseudomonas aeruginosa. Infect Immun 1984;44:508-13.

25 Cryz SJ. Furer E, Germanier R. Protection against fatal Pseudomonas aeruginosa burn wound sepsis by immunization with lipopolysaccharide and high-molecular weight polysaccharide. Infect Immun 1984;43:795-9.

26 Cryz SJ, Furer E, Germanier R. Passive protection against Pseudomonas aeruginosa infection in an experimental leukopenic mouse model. Infect Immun 1983;40:659-64.

27 Sawada S, Suzuki M, Kawamura T, Fujinaga S, Masuho Y, Tomibe K. Protection against infection with Pseudomonas aeruginosa by passive transfer of monoclonal antibodies too lipopolysaccharides and outer membrane proteins. $J$ Infect Dis 1984;150:570-6.

28 Pollack M, Young LS. Protective activity of antibodies to exotoxin A and lipopolysaccharide at the onset of Pseudo-? monas aeruginosa septicemia in man. $J$ Clin Invest 1979:63:276-86.

29 Pollack M, Longfield RN, Karney WW. Clinical significant of serum antibody responses to exotoxin $\mathrm{A}$ and type-specific lipopolysaccharides in patients with Pseudomonas aeruginosa infections. Am J Med 1983;74:980-7.

30 Hedstrom RC, Pavlovksis OR, Galloway DR. Antibody response of infected mice to outer membrane proteins of Pseudomonas aeruginosa. Infect Immun 1984;43:49-53.

31 Lam JS, Mutharia LM, Hancock REW, Hoiby N, Lam K, Back L, Costerton JW. Immunogenicity of Pseudomonas aeruginosa outer membrane antigens examined by crossed immunoelectrophoresis. Infect Immun 1983;42:88-98.

32 Gilleland HE, Parker MG, Matthews JM, Berg RD. Use of a purified outer membrane protein $F$ (porin) preparation of Pseudomonas aeruginosa as a protective vaccine in mice. Infect Immun 1984;44:49-54.

33 Hancock REW, Mutharia LM, Mouet ECA. Immunotherapeutic potential of monoclonal antibodies against Pseudomonas aeruginosa protein F. Eur J Clin Microbiol 1985;4:224-7.

34 Schimpff SC, Moody M, Young VM. Relationship of colonization with Pseudomonas aeruginosa to development of Pseudomonas bacteremia in cancer patients. Antimicrob Agents Chemother 1970;10:240-4.

35 Hanses EJ, Frisch CF, Johnston KH. Cell envelope proteins of Haemophilus influenzae type 6: potential vaccinogen candidates. In: Sell SH, Wright PF, eds. Haemophilus influenzae epidemiology, immunology and prevention of disease. New York: Elsevier Biomedical Press, 1982:197-206.

36 Buchanan TM, Pearce WA, Schoolnik GK, Arko RJ. Protection against infection with Neisseria gonorrhoeae by immunization with outer membrane protein complex and purified pili. $J$ Infect Dis 1977;136(suppl):S132-7.

Requests for reprints to: Dr Ruth Matthews, Department of Medical Microbiology, St Bartholomew's Hospital, West Smithfield, London EClA 7BE, England. 